\title{
User Satisfaction in the Tuberculosis Control Program in a City in Rio de Janeiro, Brazil
}

\author{
Rute dos Santos Lafaiete ${ }^{1}$ \\ Maria Catarina salvador da Motta ${ }^{2}$ \\ Tereza Cristina Scatena Villa ${ }^{3}$
}

\begin{abstract}
One way to evaluate health services is through the satisfaction of users. This study evaluates the satisfaction of users cared for by the Tuberculosis Control Program (TBCP) in a primary health care unit in Itaboraí, RJ, Brazil. Users satisfied with the services tend to adhere to their treatment, which is of course essential for successful TB treatment. This descriptive and quantitative study was carried out from December 2008 to February 2009; 88 individuals composed a non-probabilistic sample. A questionnaire validated and adapted to measure the satisfaction of individuals with tuberculosis was used. The study obtained high rates of user satisfaction. These positive evaluations can be explained by the fact these patients were included in the TBCP and were cared for by a health team with whom they established bonds and received support for treatment adherence. Studies with a qualitative approach could broaden the understanding of satisfaction and complement this study's findings.
\end{abstract}

Descriptors: Consumer Satisfaction; Health Services Evaluation, Primary Health Care; Tuberculosis.

\footnotetext{
${ }^{1}$ RN, Master's Student, Escola de Enfermagem Anna Nery, Universidade Federal do Rio de Janeiro, RJ, Brazil. E-mail: rutelafaiete@gmail.com.

${ }^{2}$ RN, Ph.D. in Nursing. Adjunct Professor, Escola de Enfermagem Anna Nery, Universidade Federal do Rio de Janeiro, RJ, Brazil. E-mail: ma.catarina@gmail.com.

${ }^{3}$ RN, Ph.D. in Nursing. Full Professor, Escola de Enfermagem de Ribeirão Preto, Universidade de São Paulo, WHO Collaborating Centre for Nursing Research Development, SP, Brazil. E-mail: tite@eerp.usp.br.
} 


\title{
Satisfação dos usuários no programa de controle da tuberculose de um município do Rio de Janeiro, Brasil
}

Uma das formas de se avaliar serviços de saúde é através da satisfação dos usuários. O objetivo do estudo foi avaliar a satisfação dos usuários do Programa de Controle da Tuberculose de uma unidade básica de saúde, em Itaboraí, RJ, já que usuários satisfeitos com os serviços tendem a aderir à terapêutica, e, relacionado à tuberculose, a adesão é fundamental para o sucesso do tratamento. Realizou-se estudo descritivo, quantitativo, de dezembro/2008 a fevereiro/2009, com 88 indivíduos, selecionados de forma não probabilística, usando-se questionário validado e adaptado para satisfação do indivíduo com tuberculose. O estudo teve como resultados altas taxas de satisfação. Essas avaliações positivas podem ser explicadas pelo doente estar inserido no programa de tuberculose e ser acompanhado por equipe de saúde com a qual ele estabelece vínculo e apoio à adesão, durante o tratamento. Estudos com abordagem qualitativa poderiam ampliar a compreensão sobre a satisfação, complementando a pesquisa realizada.

Descritores: Satisfação dos Consumidores; Avaliação de Serviços de Saúde; Atenção Primária à Saúde; Tuberculose.

\section{Satisfacción de los usuarios con el programa de control de la tuberculosis de un municipio de Rio de Janeiro, Brasil}

\begin{abstract}
Una de las formas de evaluar los servicios de salud es a través de la satisfacción de los usuarios. El objetivo del estudio fue evaluar la satisfacción de los usuarios del Programa de Control de la Tuberculosis de una Unidad Básica de Salud en Itaboraí- RJ, ya que usuarios satisfechos con los servicios tienden a adherir a la terapéutica; relacionado a la tuberculosis, la adherencia es fundamental para el suceso del tratamiento. Se realizó un estudio descriptivo, cuantitativo, de diciembre/2008 a febrero/2009, con 88 individuos, seleccionados de forma no probabilística, con un cuestionario validado y adaptado para evaluar la satisfacción del individuo con tuberculosis. El estudio tuvo como resultados altas tasas de satisfacción. Esas evaluaciones positivas pueden ser explicadas porque el enfermo se encuentra dentro del programa de tuberculosis, siendo acompañado por un equipo de salud que establece un vínculo con él y lo apoya a que adhiera al tratamiento. Otros estudios con abordaje cualitativo podrían ampliar la comprensión sobre la satisfacción complementando la investigación realizada.
\end{abstract}

Descriptores: Satisfacción de los Consumidores; Evaluación de Servicios de Salud; Atención Primaria de Salud; Tuberculosis.

\section{Introduction}

The main objective of direct health care units is to provide services with the best quality possible, involving desirable characteristics such as effectiveness, efficiency, equity, acceptability, accessibility and suitability. Several measures are used to evaluate services directly provided to the population and user satisfaction is one these measures $^{(1)}$.

Satisfaction can be defined as "positive individual evaluations of distinct dimensions of health care"(2).
However, perception of services and prior expectation of users is what one usually measures rather than satisfaction per se ${ }^{(3)}$.

Satisfaction surveys in public health services are generally carried out through questionnaires with closed questions to produce statistical data; that is, it is "objectively" measured. This quantitative method is the most frequently used and is associated with scales to measure the answers and quantify satisfaction ${ }^{(3)}$. One 
of its advantages is that one manages to reach a more representative sample of users from the population. This is from a reductionist perspective though, since one does not take into account subjective data of the phenomenon satisfaction $^{(3-5)}$. Qualitative methods, on the other hand, take into account subjective information and consider its interaction with beliefs and lifestyles.

Despite the various forms used to measure the satisfaction of users among quantitative and qualitative methods, results indicating high rates of satisfaction concerning the health sector are frequently found. This phenomenon is knows as the "elevation" effect and is reported even when expectations concerning services are negative. It may occur due to methodological aspects, theoretical inconsistencies or even due to the fact that users express high satisfaction with public services for fear of losing their right to such services $^{(6-7)}$.

Some transmissible diseases such as tuberculosis (TB) are persistent, present high rates of incidence and are considered a public health problem with deep roots that reflect an inefficient structure of the health services and also the population's poor living conditions ${ }^{(8)}$.

One of the problems related to TB is the high rate of treatment abandonment. Users satisfied with services tend to adhere to their prescribed therapy ${ }^{(7)}$ and treatment adherence is essential in the case of TB, since one of the main problems presented by the National TB Control Program refers to the non-adherence of TB patients to their treatment ${ }^{(9)}$.

Non-adherence leads to a reduced number of cases whose outcome is a cure and to an increased number of cases that develop resistance to the medication used in TB treatment. Such a context poses a great challenge to health professionals and managers who are required to search for strategies to overcome such difficulties, such as increasing treatment adherence through the users' increased level of satisfaction(10). From this perspective, one has to acknowledge how users evaluate care delivery to rethink professional practices and intervene in how the services are organized, seeking to improve health services.

User satisfaction in relation to TB control was assessed in this study from the perspective of patients, assuming that satisfaction is related to the health services' performance and how these are organized.

This study evaluated the satisfaction of users registered in the TB Control Program (TBCP) of a primary health care unit in Itaboraí, RJ, Brazil.

\section{Method}

This descriptive study with quantitative approach was conducted in the city of Itaboraí located in the metropolitan region of Rio de Janeiro, Brazil, $45 \mathrm{~km}$ from the capital. This city was chosen because it is considered one of the most important for TB control by the State Health Department: 180 TB cases were reported in 2005.

The study population was composed of 88 users of the TBCP. The following inclusion criteria were used: individuals under treatment for more than one month, who began treatment in 2008 or 2009 and individuals who concluded treatment up to six months before data collection was initiated. The exclusion criteria were: individuals younger than 18 years of age. The individuals were selected through a non-probabilistic method; the sample was composed of the total number of users who agreed to participate in the study in the data collection period.

A questionnaire was used for TB patients undergoing treatment to assess their level of satisfaction. This questionnaire was validated in Brazil and adapted to measure TB patients' satisfaction by Villa \& RuffinoNetto(11). The questionnaire contained questions addressing the levels of user satisfaction concerning the service and care delivery connected to the Primary Health Care dimensions (infra-structure, accessibility, relationship between users and health team).

The variables analyzed in this study were: physical appearance, accommodation, ventilation, availability of medication, waiting time, place where the supervised dose is provided, reception, trust, guidance, availability of professionals, and general evaluation of care delivery.

Data collection was carried out between December 2008 and February 2009 in the City Health Center in the Central Outpatient Center for Tuberculosis, where TBCP is accessible, during office hours available for medical consultations and the administration of supervised doses.

Interviewees answered each question according to a Likert scale, which was scored from zero to five. Zero was scored for answers "I do not know" or "Does not apply"; 1 to 5 scored the level of preference (or agreement) with the statements; the higher the score corresponding to the descriptor, the higher the level of satisfaction of the studied users.

As required by Resolution 196/96, the project was submitted to and approved by the Ethics Research 
Committee (Protocol 85/08). Each interviewee participated in the study after signing a free and informed consent form. This project was financially supported by the Global Fund to Fight Tuberculosis, jointly with the coordination of the Operational Research Group of the Brazilian Tuberculosis Research Network (REDE-TB) and was also supported by the Foundation for Scientific and Technological Development in Health.

\section{Results}

Table 1 - Indicators related to the level of satisfaction of users registered in the Tuberculosis Control Group in Itaboraí, RJ, Brazil - 2009

\begin{tabular}{|c|c|c|c|c|c|}
\hline \multirow{2}{*}{ Indicators } & \multicolumn{5}{|c|}{ Level of Satisfaction (\%) } \\
\hline & Regular & Good & Very good & Others & Total $(\mathrm{N})$ \\
\hline Appearance & 20.0 & 58.0 & 19.3 & 2.7 & 88 \\
\hline Accommodations & 42.0 & 41.0 & 16.0 & 1.0 & 88 \\
\hline Ventilation & 41.0 & 44.3 & 12.5 & 2.2 & 88 \\
\hline Availability of medication & 3.4 & 60.2 & 35.2 & 1.2 & 88 \\
\hline Waiting time & 36.3 & 53.4 & 8.0 & 2.3 & 88 \\
\hline Time of supervised dose & 5.6 & 71.5 & 10.0 & 12.9 & 88 \\
\hline Site of supervised dose & 9.0 & 64.0 & 19.3 & 7.7 & 88 \\
\hline Reception & 7.0 & 64.7 & 28.3 & 0.0 & 88 \\
\hline Trust in the health team & 4.0 & 62.0 & 34.0 & 0.0 & 88 \\
\hline Guidance from the health team & 7.0 & 62.5 & 29.5 & 1.0 & 88 \\
\hline Availability of professionals & 7.0 & 60.0 & 33.0 & 0.0 & 88 \\
\hline
\end{tabular}

In the evaluation of level of satisfaction for the TBCP users in Itaboraí, RJ, Brazil, the answers "very bad" and "bad", which respectively correspond to the scores 1 and 2 in the questionnaire scale, presented very low frequencies. Therefore, they were included in the item "others" together with non-answered questions. This item did not reach $10 \%$ of the total of answers.

The answer with the highest percentage was "good". Some of the variables related to the health unit's physical structure such as "appearance", "accommodations" and "ventilation" presented a lower level of satisfaction. Another variable with a low level of satisfaction was related to "waiting time", both for consultations and administration of supervised doses. The variables "reception", "trust", "guidance provided by the health team" and "availability of professionals" presented a higher level of satisfaction.

\section{Discussion}

Talking about satisfaction in public health services is not a simple task and addressing the satisfaction of users in the public system seems to be challenging because it is an aspect usually disregarded by workers ${ }^{(12)}$. The participation of the community in evaluating public health services is not always encouraged and/or valued as it is in the case of private services, which constantly assess efficiency and quality of service delivery. The concern in public services is usually focused on effectiveness, whether the health problems of patients are being solved. There is no concern, however, with the quality of care delivery.

User satisfaction has many determinants, such as: level of expectation, individual requirements in relation to care delivery and the individual characteristics of patients (age, gender, social class and psychological state). Addressing expectations is one of the most complex tasks since patients may have learned to decrease their expectations in relation to services and may also have a low critical ability. The opposite may also happen, that is, a lower level of satisfaction may occur due to one's relatively high level of expectations(2).

In relation to socio-demographic characteristics, most of the studied population is composed of men. This is explained by the fact that tuberculosis in Brazil is predominantly found among men. Data related to age also follows larger Brazilian patterns: the disease predominates among those 20 to 49 years old ${ }^{(13)}$.

Level of education is the most important indicator determining socioeconomic level. Most of the patients had a low level of education and low family income, which agree with the findings of other studies ${ }^{(13-14)}$. TB more strongly affects disadvantaged population groups. Hence, these conditions favor the development of TB and influence rates of morbidity ${ }^{(14)}$. 
Access to health services is valued in the Brazilian context, in which the population has limited or difficult access to health services, given the lack of options of other public health services, especially among lowincome users. Members of this population are the ones who seek the services to obtain medical care, medication and vaccinations. These individuals are more concerned with a minimum survival standard than with quality of existence( $^{(3)}$.

The high levels of satisfaction obtained in relation to infrastructure could be influenced by other aspects of the services such as a satisfactory result of treatment or good relationships established with the professionals. Concern with infrastructure is not the most relevant factor for user satisfaction(15), because it corresponds to stable characteristics of care, physical, material and financial resources, or building and equipment maintenance, among others. It is difficult to quantify the influence or the exact contribution of this component to the final quality of care delivery, but it is possible to talk about trends - a more appropriate structure increases the probability of the care delivery being considered to have a higher quality ${ }^{(12)}$.

The conditions of the interviewees' households should be taken into account because what may seem precarious for one seems very good for others with poor living conditions ${ }^{(16)}$. These results show the limitations of some users in evaluating the structure of public health units; one may talk about the structure of such units but not really be able to perceive whether it is good or bad(17). It is important to review the aspects related to infrastructure in order to implement the necessary structural repairs to improve the environment, accommodations and waiting time, consequently improving the dynamic of consultations and supervised medication.

The availability of medication in the health unit itself is the main factor associated with the quality of the service's problem-solving capacity and is what ensures access to TB treatment. Every user expects the services to be fast with the least waiting time possible and most users reported being satisfied in relation to wait time. This component related to TB may directly affect treatment since delay or office hours that are incompatible with a patient's work hours may lead a patient to abandon the health service and no longer seek diagnosis or treatment there. Patients may end up abandoning the treatment for fear of losing their jobs or not attending other appointments given absences and delays $^{(19)}$.
Most patients were satisfied in relation to the time and place where supervised dosages of medication are provided. It is important to keep in mind that there were people in the studied population covered by the Family Strategy Family and who probably received a different treatment, that is, they either received the supervised dose at home or in the health unit closest to their homes. This study did not evaluate the relationship between FHS and users' levels of satisfaction.

Most patients were also satisfied with the guidance provided by health professionals. Information provided to clarify aspects related to the disease, its consequences and habits that might influence treatment is very important. The level of information provided is conditioned based, among other aspects, on the level of education and efficiency of communication strategies and health information used by the services ${ }^{(4)}$.

"Relations of trust", "availability of professionals" and "reception" were considered satisfactory. The bonds established between health professionals and patients also influence adherence to the TBCP. Appropriate reception/welcome of patients is essential in the evaluation of health service quality because they lead patients to seek the services ${ }^{(7)}$.

Other studies ${ }^{(4,20-23)}$ measuring the satisfaction of users of the SUS also found a high level of satisfaction related to most of the analyzed variables. Providing positive answers is common ${ }^{(21)}$. A trend has been proven to exist among disadvantaged classes to positively evaluate services provided to them(20), probably for fear of losing their rights to such services or suffer some kind of punishment. This is contrary to the responses of more economically advantaged social classes, which tend to demand better care delivery(20).

Even with the preceding evidence, a study conducted at a national level in Brazil(24) addressing factors associated with the satisfaction of SUS users revealed that being young, exclusively using the SUS and having a low level of education indicated a greater chance of user dissatisfaction. These findings oppose those of this study since the social characteristics of TB individuals would indicate lower levels of satisfaction, which was not observed in this study.

\section{Conclusion}

This study's main results indicate high levels of satisfaction among users cared for by the TBCP in Itaboraí, RJ, Brazil. The evaluation of care delivery with a focus on the perception of the population is important 
and should be carried out by health services to improve and/or maintain the services' quality.

The positive assessments obtained in this study may be explained by the fact that the studied patients were included in a TB program and were cared for by a health team with which they established bonds and from which they received support to maintain treatment adherence. The opinion of patients concerning care delivery depends on their conceptions and values and also on how well they are welcome/received in the service. Additionally, trust and guidance provided by the health team and availability of professionals are factors, which were evaluated with a higher level of satisfaction.

Patients undergoing treatment at the TBCP can either express their opinions or resignation in relation to already established conditions. Critiques depend on the role individuals attribute to themselves within the context of health services. The fact that FHS offers supervised treatment to patients in its scope area reduces costs from transportation and favors access, the establishment of bonds, and TB treatment adherence.

Hence, studies with a qualitative approach could enlarge the understanding of satisfaction since the values, beliefs, and representations of health services and TB treatment held by individuals certainly influenced this study's findings and they should also be investigated to contribute to the assessment of care delivered by the TBCP in Itaboraí, RJ, Brazil.

\section{References}

1. Akerman M; Nadanovsky, P. Avaliação dos Serviços de Saúde - Avaliar o Quê. Cad Saúde Publica. $1992 ; 8(4): 361-5$.

2. Vaitsman J, Andrade GRB. Satisfação e responsividade: formas de medir a qualidade e a humanização da assistência à saúde. Ciênc Saúde Colet. 2005;10(3):599-613.

3. Esperidião $M$, Trad LAB. Avaliação de satisfação de usuários. Ciênc Saúde Colet. [internet]. 2005 [acesso 22 ago 2009]; 10:303-12. Disponível em: http://redalyc. uaemex.mx/redalyc/pdf/630/63009931.pdf

4. Trad LAB, Bastos ACS, Santana EM, Nues MO. Estudo etnográfico da satisfação do usuário do Programa de Saúde da Família na Bahia. Ciênc Saúde Colet. $2002 ; 7(3): 581-9$

5. Bosi ML, Affonso KC. Participação popular e saúde: com a palavra, os usuários da rede pública de serviços. Cad Saúde Pública. 1998;14(2):355-65.
6. Gomes R, Silva CMF, Deslandes SF, Souza ER. Avaliação da assistência ambulatorial a portadores de HIVAIDS no Rio de Janeiro, segundo a visão dos usuários. Cad Saúde Pública. 1999;15(4):789-97.

7. Lima MADS, Ramos DD, Rosa RB, Nauderer TM, Davis

R. Acesso e Acolhimento em Unidades de Saúde na Visão dos Usuários. Acta Paul Enferm. 2007;20(1):12-7.

8. Esperidião MA, Trad LAB. Avaliação de satisfação de usuários: considerações teórico-conceituais. Cad Saúde Pública. 2006;22(6):1267-76.

9. Halfoun VLRC, Aguiar OB, Mattos DS. Construção de um Instrumento para Avaliação de Satisfação da Atenção Básica nos Centros Municipais de Saúde do Rio de Janeiro. Rev Bras Educ Méd. 2008;32(4):424-30.

10. Ministério da Saúde (BR). Secretaria Executiva. Departamento de Apoio à Descentralização. Coordenação Geral de Apoio à Gestão Descentralizada. Diretrizes operacionais do pacto pela vida em defesa do SUS e de Gestão. Brasília: Ministério da Saúde; 2006.

11. Villa TCS, Ruffino-Netto A. Questionário para a avaliação de desempenho de serviços de atenção básica o controle da TB no Brasil. J Bras Pneumol. 2009; 35(6):610-2.

12. Malik AM, Shiesariri LMC. Qualidade na gestão local de serviços e ações de saúde. São Paulo: Faculdade de Saúde Pública da Universidade de São Paulo; 1998.

13. Santo LALA, Santos PCH, Moreira ME. Perfil clínico, epidemiológico e laboratorial dos pacientes com tuberculose em hospital universitário da região do Vale Paraíba, Estado de São Paulo. Bepa. ago 2009;6(68):14-21.

14. Santos MLSG, Vendramini SHF, Gazetta CE, Oliveira SAC, Villa TCS. Poverty: socioeconomic characterization at tuberculosis. Rev. Latino-Am. Enfermagem. set-out 2007;15(no esp):762-7.

15. Santos JF, Brunello MEF, Scatena LM, Andrade RLP, Villa TCS. Satisfação do doente de tuberculose em relação à infra-estrutura dos serviços de saúde, Ribeirão Preto (2008-2009).[internet]. $17^{\circ}$ Simpósio Internacional de Iniciação Científica da Universidade de São Paulo. [acesso 9 fev 2010]. Disponível em: http://www.usp.br/ siicusp/Resumos/17Siicusp/subarea_tit_CI_12.htm 16. Andrade KLC, Ferreira EF. Avaliação da inserção da odontologia no Programa Saúde da Família de Pompéu (MG): a satisfação do usuário. Ciênc Saúde Colet. 2006; 11(1):123-30.

17. Ferri SMN, Pereira MJB, Mishima SM, Caccia-Bava MCG, Almeida MCP. As Tecnologias Leves com Geradoras de Satisfação em Usuários de uma Unidade de saúde da Família. Comunic Saúde Educ. 2007;23(11):515-29. 
18. Halal IS, Sparrenberger F, Bertoni AM, Ciacomet

C, Seibel CE, Lahude FM. Avaliação da qualidade de assistência primária à saúde em localidade urbana da região sul do Brasil. Rev Saúde Pública. 1994;28(2):131-6.

19. Morrone N, Sollha MSS, Cruvinel MC, Morrone $N$ Junior, Freire JAS, Barbosa ZLM. Tuberculose: tratamento supervisionado "vs." tratamento autoadministrado Experiência ambulatorial em instituição filantrópica e revisão da literatura. J Bras Pneumol. 1999; 25(4):198-206.

20. Lemme AC, Noronha G, Resende JB. A satisfação do usuário em hospital universitário. Rev Saúde Pública. 1991;25(1):41-6.

21. Kotaka F, Pacheco MLR, Higaki Y. Avaliação pelos usuários dos hospitais participantes do programa de qualidade hospitalar no Estado de São Paulo, Brasil. Rev Saúde Pública. 1997;31(2):171-7.

22. Bulgarelli AF, Manco ARX. Idosos vivendo na comunidade e a satisfação com a própria saúde bucal. Ciênc Saúde Colet. 2008;13(4):1165-74.

23. Emmi DT, Barroso RFF. Avaliação das ações de saúde bucal no Programa Saúde da Família no distrito de Mosqueiro, Pará. Ciênc Saúde Colet. 2008;13(1):35-41. 24. Gouveia GC, Souza WV, Luna CF, Souza-Junior PRB, Szwarcwald CL. Satisfação dos usuários do sistema de saúde brasileiro: fatores associados e diferenças regionais. Rev Bras Epidemiol. 2009;12(3):281-96. 